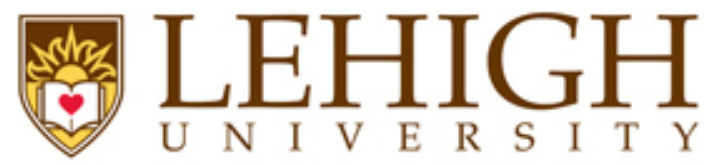

ARIEL
UNIVERSITY
PRESS

Archaeology and Text: A Journal for the Integration of Material Culture with Written Documents in the Ancient Mediterranean and Near East

Vol. 1, 2017 
Archaeology and Text: A Journal for the Integration of Material Culture with Written Documents in the Ancient Mediterranean and Near East

\section{Editors}

David Small, Lehigh University.Email dbs6@lehigh.edu

Itzhaq Shai, Ariel University.Email: shai.itzick@gmail.com 


\section{Editorial Board:}

Yonatan Adler, Department of Land of Israel Studies and Archaeology, Ariel University

Colleen Darnell, Department of Art History, University of Hartford

Thomas Gallant, Department of History, University of California at San Diego

Onno van Nijf, Department of History, University of Groningen

Robin Osborne, Faculty of Classics, Cambridge University

James Whitley, School of History, Archaeology, and Religion, Cardiff University

K. Lawson Younger, Jr., Department of Old Testament and Semitic Languages, Trinity International University 


\section{Table of Contents}

Divination Texts of Maresha - Archeology and Texts

Esther Eshel, Bar Ilan University, Ian Stern, Archaeological Seminars Institute

Toward an "Archaeology of Halakhah": Prospects and Pitfalls of

Reading Early Jewish Ritual Law into the Ancient Material Record

Yontan Adler, Ariel University

27

Purity Observance among Diaspora Jews in the Roman World

Jodi Magness, University of North Carolina at Chapel Hill

Visual Models in Archaeology and Harmonization of Archaeological

and Literary Data Catalin Pavel, Kennesaw State University

Reading Between the Lines: Jewish Mortuary Practices in Text and Archaeology Karen B. Stern, City University of New York, Brooklyn College

Complex Purity: Between Continuity and Diversity in Ancient Judaism 


\section{Editorial Statement}

The study of the human past has conventionally been divided between two distinct academic disciplines depending upon the kind of evidence under investigation: "history", with its focus on written records, and "archaeology", which analyzes the remains of material culture. This new annual publication, Archaeology and Text: A Journal for the Integration of Material Culture with Written Documents in the Ancient Mediterranean and Near East, aims to bridge this disciplinary divide by providing an international forum for scholarly discussions which integrate the studies of material culture with written documents. Interdisciplinary by nature, the journal offers a platform for professional historians and archaeologists alike to critically investigate points of confluence and divergence between the textual and the artifactual.

We seek contributions from scholars working in the ancient Mediterranean and Near East. Contributions with a theoretical or methodological focus on the interface between archaeology and text are especially encouraged. By publishing all of its articles online, the Archaeology and Text seeks to disseminate its published papers immediately after peer-review and editorial processes have been completed, providing timely publication and convenient access.

In providing a forum, we will publish reviews of recent publications which deal with the issue of archaeology and text. When appropriate, each volume will include a short overview of recent conferences which have treated this topic as well. 


\section{Recent Conferences focused on the Issue of Archaeology and Texts}

Archaeology and Text: Toward Establishing a Meaningful Dialogue between Written Sources and Material Finds

Conference held on Sunday May 10 - Monday May 11, 2015. Sponsored by Ariel University and the Israel Ministry of Science, Technology, and Space. Conference was organized into several small sessions. Papers ranged from those dealing with the issue of archaeology and texts in the Near East to those focusing on this issue in Mediterranean Studies. Topics ranged from the application of textual material to singular sites - Text and Archaeology: the Case of Tel Rehov in the 10-9 $9^{\text {th }}$ Centuries BCE, A. Mazar - to more theoretical contributions - Purity and Purification in the Dead Sea Scrolls and the Mikva'ot of Qumran: the Convergence of Archaeology and Text, L. Schiffman.

Textual Archaeology of Ancient Near East: Are We Doing it Wrong?

Conference held on Thursday December 10 - Sunday December 13, 2015. Sponsored by the McDonald Institute for Archaeological Research, Cambridge University. Conference was subdivided into various sessions with invited responses. Topics focused on issues pertaining to the Near East with a few inclusions of cases dealing with the Bronze Age Aegean. Papers ranged from those treating the issues of the uses of archaeology and texts in broad areas in the Near East, such as Assyriology - Of Haematite and Apricots: Matching up the Mesopotamian World, N. Postgate - to contributions touching upon landscape - Satellite Remote Sensing, Archaeological Survey, and Historical Geography in Northern Mesopotamia, J. Casana - the analysis of texts in ancient Mayan studies - Histories of Decline and Fall: Archaeology, Epigraphy, and the Maya Collapse, N. Carter.

The Conference is being published by the McDonald Institute, with its organizer, Y. Heffron as the editor. 


\title{
Complex Purity: Between Continuity and Diversity in Ancient Judaism
}

\author{
Yair Furstenberg, Ben Gurion University of the Negev
}

Review of:

Stuart S. Miller, At the Intersection of Texts and Material Finds: Stepped Pools, Stone Vessels and Ritual Purity among the Jews of Roman Galilee (Göttingen: Vandenhoeck \& Ruprecht, 2015)

\section{Varieties of Ritual Purity}

Second Temple literature testifies to the centrality of ritual purity in shaping private conduct as well as group identity among the Jews of Palestine. While in the Priestly Code the laws of purity are geared towards maintaining the sanctity of the sanctuary (Leviticus 12-15) by isolating it from lepers, carriers of genital discharges, and anyone coming in contact with a dead corpse (Num 5:1-4, 19:20), in the Second Temple period the fear of contamination largely dominated the daily life of many. Literary sources relate to purification after contact with a corpse or following sexual relations as a standard practice, and Josephus mentions not only the expulsion of those inflicted by severe impurity, but the regular isolation of women during their menstruation period. ${ }^{1}$ He further quotes the decree of the Seleucid king, Antiochus III, prohibiting the importation of impure animals and artifacts into Jerusalem, and warning non-Jews from entering the Temple precincts. ${ }^{2}$ Furthermore, gentile impurity even appears to have influenced commercial relations, since Jews avoided importing foreign oil, as well as glass and clay vessels, from abroad. ${ }^{3}$ According to the Acts of the Apostles, Jews were even careful not to enter the houses of gentiles (Acts 10:28). Finally, as we learn from the same group of Jesus followers, many Jews awaited an era of absolute purification from worldly sorrows, putting their trust in contemporary prophets such as John the Baptist and Jesus, while participating in their acts of purification. ${ }^{4}$

\footnotetext{
${ }^{1}$ Tob. 2:5; Philo, Laws 3:63, 205-206; Josephus, AgAp 2:198, 203; Ant 3:261-262.

2 Josephus, Ant 12:145-146.

${ }^{3}$ See Goodman 2007: 187-203 for evidence of Jewish observance of kosher olive oil.

${ }^{4}$ I discuss the formation of rituals for purification from sin in Qumran and Early Christianity in Furstenberg $2016 \mathrm{~b}$.
} 
As much as purity manifested itself as a common concern, the dominance of purity is most evident within the writings of those elitist groups, who sought to distinguish themselves from the multitude, and whose claim for religious authority was rooted in the recognized value of their unique purity practices. The Jerusalem priests, the Pharisees (and haverim), Essenes, and the Qumran Sectarians all held themselves to be in a superior purity status in comparison to the common people (am ha-arets, "people of the land", in rabbinic jargon). Concurring with their extreme separatism, the Essenes identified outsiders as gentiles with respect to their level of impurity. ${ }^{5}$ The Pharisees were more lenient in their dealings with non-members but were still careful to limit contact with them. As in the case of the Jerusalem priests, purity was commonly conceived as a signifier of religious status, and it was therefore essential in the creation not only of holy space, in Jerusalem and the Temple, but of social hierarchy as well. ${ }^{6}$

Following this heritage, rabbinic literature, created after the destruction of the Temple, exhibits the same basic features apparent in Second Temple sources. First, it indicates the significance of purity beyond the realm of the Temple. It assumes that despite the destruction of the Temple, there is still a continuing obligation to maintain purity laws, first and foremost for the sake of the priestly offerings, terumah and ma 'aser, which continued to be separated and given to the priests in a state of purity. Second, rabbinic literature refers to the existence of distinct levels of purity and to the role of the associations (havurah) in supporting the effort of those who wished to eat their daily food in a state of purity. ${ }^{7}$ Like their Pharisaic predecessors, the rabbis assumed all were obligated to observe a basic level of purity, while they distinguished themselves from others through a more intense involvement in purity. The result of this effort is evident in the extensive treatment of purity in order Purities of the Mishnah, covering every aspect of daily life and organizing one's complete environs. ${ }^{8}$ The fact that purity was not limited to the Temple, as we learn from the literary sources, explains its enduring presence, in rabbinic literature as well as in the material culture of the following centuries.

In light of the unprecedented role of purity among Second Temple Jews, it comes as no surprise that artifacts of purity are major signifiers of Jewish material culture. Stepped pools, identified as miqwa'ot for purification, are a standard feature of Jewish settlements during this period, beginning in Judea in the first century BCE and continuing

\footnotetext{
${ }^{5}$ Josephus, War 2: 150

${ }^{6}$ Regev 2000; Furstenberg 2015, 2016 a.

${ }^{7}$ m. Demai 2:3; t. Demai 2:2-12.

${ }^{8}$ For an excellent presentation of the significance of purity in rabbinic literature see Balberg 2014.
} 
beyond $70 \mathrm{CE}$ and the Bar Kokhba Revolt into the Late Roman and Byzantine period, in southern Judea and beyond into the Jewish settlement in the Galilee. The same is true concerning the second feature of purity material culture, stone vessels. Due to their insusceptibility to impurity, stone vessels served to secure foods from the threat of contamination. Large numbers of such vessels were found in the Jerusalem area, in keeping with the extraordinary purity needs of the city. However, in contrast to the assumption of earlier scholars, we now know that their production did not cease after the destruction of the Temple and there is now evidence for their continued usage in Later Roman Galilee. True, in this period the numbers of both stepped pools and stone vessels declined, but they are still a component of Jewish material culture. ${ }^{9}$

The material finds seem, then, to ratify the literary evidence and point to the same general picture: concern for purity was not limited to the Temple and continued to thrive after its destruction among considerable groups in Palestine, albeit in a more limited manner, into the Byzantine period. This agreement is quite extraordinary, considering the tension between rabbinic literature and material culture apparent in other spheres of Jewish life in antiquity, such as in the case of synagogues or legal documents. In addition, until recently the tendency among both archaeologists and scholars of rabbinic literature was to limit the impact of purity in daily dealings and confine it to the scholarly interests of small marginal groups such as the rabbis or members of purity associations. Recent surveys and current interpretive methods of rabbinic literature go hand in hand in reassessing the intensity of the ritual world in Jewish antiquity.

However, this correlation is only the preamble for a more nuanced and sophisticated scholarly task: offering an integrated evaluation of the role of purity in ancient Judaism. As evident from both Second Temple and rabbinic literature, ritual purity held different meanings for different groups and it was a mutable and multidimensional category, within both popular and more ideological circles. This range of competing values requires a better assessment of the relationship between the literary and the material evidence for understanding this phenomenon as a whole. Taking into account the inherent tension between the ideological and even separatist literary works and the common interests embedded in the widespread material culture, we must ask whether these bodies of evidence add to a coherent image of purity culture, or do they represent disparate aspects of this multifaceted phenomenon?

The relationship between texts and material finds breaks down into three separate levels: First, in light of the differing practices attested to in the literary sources, the

\footnotetext{
${ }^{9}$ See Adler 2014 for a useful survey.
} 
most basic question is what system of halakhah (Jewish law) fits the material finds best. Do the specificities of the physical finds, size, structure, and material, correspond to the rulings of one of the groups known from our literary sources, such as the Pharisees, Sadducees, Essenes, or Rabbis, and do they testify to the dominance of a specific system of law? This question is crucial in light of the debate concerning the extent of pharisaic dominance over popular Jewish practices, ${ }^{10}$ and the affinity of the Pharisees' way of life to "Common Judaism". ${ }^{11}$ On the second level, what does the integration of literary and material evidence tell us about how Jews understood the purpose of preserving purity? Can the material finds expose alternative approaches to purity, hidden or marginalized by the peculiar interests of the authors of Second Temple or rabbinic texts? Having considered the relationship between particular and popular practices and the purpose of popular purity against the notions expressed in the literary source, we come to the third level: how did the diverse practices and conceptions of purity shape social fabric? Is it appropriate to speak of a "Common Judaism" or were there distinct "Judaisms" separated by their forms of purity, serving to delineate social boundaries, ${ }^{12}$ or was there some form of symbiosis between the different manifestations of purity? While texts tend to present a polarized picture and set themselves in opposition to their halakhic and ideological interlocutors, the material findings demand of us a more sophisticated account of the ties and interdependencies between the differing practices within a shared material and social framework.

In his remarkably comprehensive book, At the Intersection of Texts and Material Finds, Stuart Miller exhibits his original and balanced approach towards the diversity of literary and material sources and arrives at new answers to all three issues. Instead of interpreting the stepped pools and the stone vessels against the halakhic, ideological, and social background outlined by rabbinic texts, Miller seeks to understand the array of peculiar notions as by-products of the underlying material culture shaped by common interests as well as social and economic circumstances. The finds represent the common ground from which specific halakhic conceptions and more developed notions of purity sprung. By their very nature, material findings reflect a more popular and elusive form of ritual, which was later crystalized by more learned and ideological groups as they negotiated their ritual environment.

Taking his cue from the archaeology of ancient synagogues that have revealed new forms of Jewish practice irrespective of rabbinic instruction, Miller attempts to describe

\footnotetext{
${ }^{10}$ For example, Mason 1990.

${ }^{11}$ This is the assumption of Gedalyahu Alon in his seminal paper on purity in ancient Judaism, "The Bounds of the Laws of Levitical Cleanness," (Alon 1977: 146-189).

${ }^{12}$ Compare Sanders 1994 and Neusner 1978.
} 
a distinct form of common purity that is biblical rather than rabbinic in nature. He therefore understands specific rabbinic requirements as deriving from and responding to this emerging material culture, and not as shaping it, as previously assumed. The same is the case with respect to the purpose of common purity. Miller deduces the common conception of purity primarily from the specific setting of the archaeological finds, and he sets them against alternative conceptions. The material finds provide the sole foundation for interpreting the form and purpose of common practice. This is the basis for Miller's construction of a "Complex Common Judaism" that retains a close relationship with specific ideologies but cannot be reduced into them. Miller's approach is highly suggestive and considerably advances our understating of the interplay of legal production and material culture. At the same time, as I survey his position, I offer a reconsideration of what is in my view the indispensable role of legal framework in shaping and maintaining a constant purity material tradition. ${ }^{13}$

\section{Material Finds as Legal Artifacts}

The ritual baths in Palestine, of which over 850 were found in various settings: domestic, public, pilgrimage, and agricultural, dating from the end of the Hellenistic period up to Late Antiquity, are distinct in their physical features, which set them apart from other water installations. ${ }^{14}$ The measures of these baths also correspond in their size and shape to the legal instructions laid out in later rabbinic literature. This fact creates the impression that these structures are a designated ritual institution, created from the very start to fit the needs of ritual law. Consequently, it seems appropriate to interpret the specificities of these baths following rabbinic principles as these were formulated in the Mishnah, and which the commissioners of the miqwa'ot presumably followed.

As Miller demonstrates at the very head of the book, this scholarly approach has found strong corroboration with the findings of a unique double bath installation at Masada (17-20). This compound is strikingly similar to the familiar halakhic

\footnotetext{
${ }^{13}$ The following discussion will not relate to chapters that do not address these core issues, as I understand them. Chapter 4 discusses P. Oxyrhynchus 840, which mentions Jewish immersion. Despite the illuminating analysis of the notion of Jesus as living water, the chapter does not shed light on Jewish practices. Most of chapter 9 examines the status of priests. It barely relates to purity and its relevance is only in the negative conclusion concerning the marginality of priests during the post destruction period. In chapter 10 Miller turns to medieval Judaism for additional examples of nonrabbinic purity. It is doubtful however whether these cases concerning highly rabbinized medieval communities represent a separate, biblically oriented Judaism. See more below.

${ }^{14}$ Reich 2013; E.P. Sanders 1990: 216-219; Amit and Zissu 2008: 47-62.
} 
mechanism of 'otsar ('treasury'), by which a reservoir of undrawn water validates the drawn water in the adjacent bath, thus enabling the replacement of waters in the main immersion bath. This system reflects a complex array of halakhic principles, including the requirement of a minimal amount of undrawn rainwater; the permission to refill the rest of the bath with fresh drawn water; and the validation of these waters through mere contact with the separate reservoir. Finding such double baths enhanced the tendency to view the architecture of the ritual baths as direct products of Pharisaic teachings, most systematically expressed in the writings of the Rabbis. This correlation entailed a more elaborated attempt to identify the variety of archeological finds with distinct halakhic positions of the different parties of Second Temple Judaism. Scholars sought to find on the ground the same tension and variation of ideology and practice as in the literature of the period. Thus, the distribution of double installations, presumably based on the principle of purifying a bath through a separate body of water (nissoq), alongside other stand-alone baths, came to represent Pharisaic presence in the different localities. Large immersion pools with a double entrance were associated with the stringent Sadducean practice, and pools with a bottom step large enough to contain a minimal amount of undrawn water, as well as pools for immersing hands, were viewed as Pharisaic constructions. ${ }^{15}$

In chapters 1-3 Miller quite arguably refutes these prior attempts to subject the finds to rigid halakhic considerations. However, in this process he arrives at the opposite extreme and denies the applicability of halakhic literature for the interpretation of archeological findings. As in ancient synagogue architecture, which was evidently prone to surrounding influences but not to rabbinic supervision -- rather, the halakhic authorities were compelled to respond to current tendencies -- the miqwa'ot as well, Miller argues, were not constructed by the rabbis and in accordance with their laws (45-46). To the contrary, common practice set the stage for the rabbis to formulate the legal principles of valid immersion pools. Miller is no doubt justified in his critique of the simplistic inference from law to findings and in his call for a more sophisticated account of the relationship between the two. At the same time, I would argue that with respect to the system of purity observance, the material culture is strongly in debt to the legal framework and rationale set by the literary sources.

Miller shows (ch. 2) that rabbinic sources do not assume a standard structure, but they refer to various kinds of pools, including natural reservoirs and baths, created for other purposes besides purification. He points out that the rabbis never insist that the bath serve exclusive purification needs, and thus he dismantles the image of the immersion pool as a designated ritual artifact constructed strictly for the sake of

\footnotetext{
${ }^{15}$ Regev 1996; Grossberg 2007; Elitsur 1999.
} 
purity (51). He introduces the notion of the non-monolithic ritual baths, which vary in accordance with changing physical circumstances and practical needs (see 189). Miller thus follows in the footsteps of Yonatan Adler, who argued most persuasively that the double adjacent baths are not halakhic constructs. ${ }^{16}$ These were not intended to preserve a minimal amount of undrawn water, as previous scholars have conjectured on the basis of the modern 'otsar installations, but rather they served various practical functions as a separate ritual bath, settling tank, or storage. In this respect, practical considerations surely take precedence over anachronistic legal constructions in the interpretations of the material finds.

At the same time, in an attempt to release the findings from the grip of rabbinic assumptions Miller moves on to reconstruct an alternative practice, which in direct opposition to the rabbinic tradition validates drawn water for purification (ch. 3, pp. $72,84,89-93$ ). As far as I can tell, he does not adduce positive proof for this practice ${ }^{17}$ beside the assumption that the demand for undrawn water is a rabbinic innovation and is not biblically sanctioned. ${ }^{18}$ Despite the fact that the stringent rabbinic notion resonates in Qumran literature as well, ${ }^{19}$ Miller insists on reconstructing a biblically based purity system completely independent of the interpretations and traditions of later legal corpora. This suggested system validates any kind of rainwater, even if not naturally collected. ${ }^{20}$ Thus, the findings serve Miller not only to introduce some practical considerations of ritual bath construction but as testimony of an alternative form of purification.

Yet, in contrast to the remarkable disparity between the material finds and the textual horizon of expectations in the case of the ancient synagogues, no such tension exists in the case of ritual pools. I find no conclusive evidence for a non-rabbinic approach to

\footnotetext{
${ }^{16}$ Adler 2014b.

${ }^{17}$ The case of the bet tevilah (immersion room in the Temple, $m$. Middot 5:3) represents, according to Miller, a pre-rabbinic practice (309-311). Since it was situated on an upper floor, it seems not to fit rabbinic requirements concerning connection to the ground. But, since the immersion room is part of a construction connected to the ground, this case cannot provide decisive proof for a non-rabbinic practice.

${ }^{18}$ Following Sanders 1990: 219-221.

${ }^{19}$ See discussion on CD 10:10-13 on pp. 81-82, 89.

${ }^{20}$ Note, however, that this suggestion leaves open a basic issue concerning the purifying nature of water the ancients could not have overlooked. Water serves both and at same time as the ultimate purifier and the most dangerous conduit of impurity. While scripture does not define which waters are pure, it states that a spring or a cistern holding water is clear (Lev 11:36). If, following Miller's suggestion, we do not hold to the rabbinic distinction between natural and humanly drawn waters, what would re-purify the waters that were already artificially drawn and invalidated by human usage? I therefore think rabbinic interpretation is both the most plausible and practical interpretation of scripture at this point.
} 
purity and alternative means of purification. Moreover, the relatively early formation of distinct, albeit not exclusive, installations for purity reflects the specific and unique needs they came to serve and that could not be accommodated by other means, such as bathhouses and their like. Admittedly, these distinct installations do not disclose the roots of their separate development, and the necessary ritual and conceptual framework is provided primarily by the rabbinic sources. The need to maintain the water in its natural undrawn state, as presented in rabbinic sources, offers the most suitable case for the rise of the unique material findings, and at the same time, it clarifies the means for using these installations in the most practical manner.

The case of stone vessels discussed in chapter five presents us with similar methodological considerations. This unique finding is characteristic of Herodian Jerusalem and appears in diminishing numbers in the post-70 CE period up to the fifth century. If it were not for rabbinic exclusion of such vessels from susceptibility to impurity, it would be nearly impossible to justify the immense efforts put into this stone industry. More than the immersion pools, stone vessels are exclusive ritual artifacts and are practically worthless outside this context. Some stringent groups may have rejected rabbinic leniency towards stone vessels (this depends on the interpretation of some Qumran texts), ${ }^{21}$ but anyhow, one cannot imagine the evolution of this expensive industry without the clear ritual incentive, supplied by rabbinic rulings. Consequently, the extent of this finding served scholars as a direct indication for the scope of purity observance among the Jewish population. During the Second Temple period "purity burst" in Jerusalem, ${ }^{22}$ it carried on in Judea after the destruction and survived on a minimal scale up to the fifth century in the Galilee. Miller acknowledges the ritual value of the stone vessels, but at the same time downplays this aspect, known primarily from rabbinic texts, as a secondary outcome of the stone industry of the Herodian period. In his view, the changes in the extent of stone vessels primarily reflect technological and economic circumstances, and not a change of ritual practice. Only after the establishment of this industry, some people such as the rabbis saw this as an opportunity to enhance purity observance and deemed the vessels pure.

\footnotetext{
${ }^{21}$ See pp. 95-96. A good number of stone vessels were found in Qumran, but at the same time the literary evidence (11QT ${ }^{\text {a }}$ 49:14 and CD 12:15-16) has been understood as indicating that stone vessels are susceptible to impurity. Note however that both sources refer specifically to moist vessels, and they are the substances conveying impurity, not the stone itself.

${ }^{22}$ In contrast to Miller, pp. 169-172, I accept Adler's position that the reference to the "burst of purity" in an earlier period in $t$. Shabbat 1:14 goes back to the Temple period and not to the later rabbinic period (Adler 2014a; Furstenberg 2016a: 1). To my mind, the literary context referring to the Houses of Shammai and Hillel makes the association to the Temple period quite clear.
} 
Here again, I find it hard to accept the elimination of ritual literature from the interpretation of these findings, while in fact it supplies the most plausible foundation for the rise of the unique material culture that developed in Judea. Once the technology is accessible, it provides an excellent solution for the daily management of the enduring threats of contamination (while earthen vessels are not only susceptible to impurity, but must be broken once they are defiled). It is therefore safe to argue that the extent of stone vessels in Second Temple Judea testifies to the exceptionally high motivation to develop such a peculiar material environment. As long as purity was considered a major social value, the purity industry was not only a worthwhile investment but it is economically reasonable to assume that it met the highest standards set by legal authorities.

We lack a clear picture of the industry of stone vessels in the Galilee, but in any rate, it must have been relatively restricted in comparison to its Jerusalem antecedent. Miller is certainly right to conclude that this diminution cannot testify to the termination of purity. It does however offer some insight to the fundamental change that took place in the presence of purity in the public sphere. If we assume the technology of stone vessel production persisted (as the recently found quarry near Nazareth reveals), we must assume that at this stage these utensils were intended for the relatively few, who were careful to regularly eat their foods in a state of purity, and therefore took care to maintain designated utensils. All others, who observed purity only occasionally, managed well enough with their standard food ware. What was a widespread norm in Judea of the first century CE and shaped the industry and market of vessels had now become an exceptional practice of a virtuous few, who did not leave much of an imprint on the material culture.

\section{The Purpose of Purity Observance}

The many ritual baths in the Jerusalem vicinity presumably served the needs of the Temple, the pilgrims and their markets, and the priests who received holy foodstuff. The location of these baths determined the immediate context for interpreting their purpose and the kind of purity they supported. Against this model, how should we understand the purpose of the twenty or more ritual baths found in the western acropolis of Sepphoris, ${ }^{23}$ away from Jerusalem and postdating 135 CE? This question sets the stage for the second section of the book (ch. 6-10), and here Miller adds to his reconstruction of non-rabbinic purification practices, in the previous section, a novel explanation of

${ }^{23}$ Or the ritual baths at Susiya in the southern Hebron hills, for that matter. 
the purpose of purity, independent of the image of purity in rabbinic literature, based primarily on the location of the ritual baths. Since there is no conclusive evidence for a dominant presence of priests in Sepphoris, as Miller demonstrates in detail in chapter nine, which could have explained the role of the miqwa'ot along the lines of the Jerusalem findings. How should we understand the purpose of the Sepphoris ritual baths within contemporary religious culture ${ }^{24}$ The interpretive key, according to Miller, is the domestic setting of these baths, which points to a specific concern for purity pertaining to sexual relations: following menstruation and after seminal emission (ch. 8).

Domestic purity, Miller further argues, is not only distinct from priestly oriented purity, but it took hold as a substitution for the Temple and compensated for its loss (ch. 7, p. 204). Miller thus sets clear boundaries between three forms of purity: Temple and priestly purity, the rabbinic $\backslash$ Pharisaic approach to purity, and the newly enhanced popular purity. Following scholars who view the destruction as a turning point in the nature of Jewish religiosity, from institutionalized ritual to individual internalization of religious consciousness, ${ }^{25}$ Miller suggests that the loss of the Temple entailed a heightened awareness of purity within the personal sphere. The holiness of Israel, manifested in the care for domestic purity, replaced the holiness of the Temple. Miller goes on to claim that this form of purity is unique not only in its practice (the use of drawn water) and in its focal point (the family) but also in its source of authority. This popular purity (what we may term am ha-arets purity) disregarded the elaborate rabbinic instructions and rested directly on scripture (208). In fact, the tension between the rabbis and popular modes of purity is demonstrated in rabbinic literature itself. A collection of stories in the Palestinian Talmud relates to sinners and fornicators who were very careful to immerse, and to commoners who were willing, despite rabbinic resentment, to risk their lives for the sake of purification after sex. The rabbis even castigate those who practiced morning immersion rather than study Torah. ${ }^{26}$ The ritual baths in Sepphoris belong, Miller suggests, to the world of such commoners, with their own separate form of purity.

However, as in the previous section, there seems to be more room for integrating the material finds into the complex rabbinic portrayal of closely related forms of observance

\footnotetext{
${ }^{24}$ Compare Adler 2014a: 81: 'We may speculate that these settlements held a strong priestly presence, or perhaps were home to members of lay havurah societies dedicated to the regular observance of the ritual purity laws within the framework of a surrounding Jewish society which no longer adhered to these strictures.'

${ }^{25}$ Stroumsa 2009.

${ }^{26}$ y. Berakhot 3:4, 6c. See Kiperwasser 2012 for further analysis of this unit.
} 
among rabbis and others. Miller recurrently emphasizes that domestic purity replaced the Temple purity. He rejects the claim put forth by Adler of a continuous decrease in purity observance ${ }^{27}$ and prefers an exchange paradigm: One form of purity emerged with the loss of the former dominant form, and therefore the number of findings over both periods is irrelevant to our understanding of the developments in this field (323). This reconstruction is quite telling, but the comparison of Second Temple sources to later rabbinic literature clearly points to substantial continuity in the nature of popular observance of purity, and there is no evidence for an amplification of these tendencies in later periods. As mentioned above, early authors such as Philo and Josephus (quoted by Miller, p. 231) testify to daily purifications following corpse defilement and sexual contact. Thus, later rabbinic evidence for the separation of menstruants and purification after sexual relations corresponds to Second Temple practice, and there is no need to assume that the destruction motivated the rise of alternative expressions of piety. Furthermore, already during the Temple period we find new forms of purification, such as hand purity, intended for the protection of the individual (see Mark 7:1-23, discussed on p. 215-222). The findings from Sepphoris are in line with earlier finds from Judea, and it therefore makes most sense to interpret them as sections of one continuous, and at the same time complex, phenomenon.

A strong continuity exists not only between different periods but also between the different forms of purity. These are much more defused than the monolithic impression suggested at times in the book. On an analytical level, the separation of different motivations is indeed helpful, but in practice, the varied forms of purity are hardly distinguishable. Purity observance provided a shared space for a range of practices and purposes undivided by clear-cut boundaries. First, the care for the purity of the priests and their foods had a direct impact on the daily conduct of each person, who was obliged to separate pure heave-offerings from his own fruits. As rabbinic sources testify, those who were not competent in matters of purity and could not maintain the purity of the priestly share on their own turned to professionals who separated it for them. ${ }^{28}$ Consequently, even those who lacked a consistent and active commitment to purity were compelled to support the priests' obligation to maintain their share in purity.

Rabbinic sources also uncover the affinity between popular care for purity and more established forms. On all levels, purity was associated primarily with eating (and

\footnotetext{
${ }^{27}$ This is also the position I adopt in my detailed account of the history of purity observance, as seen from rabbinic perspective (Furstenberg 2016a).

${ }^{28}$ See $t$. Demai 3:1-8 examples of professional associates (haverim) separating heave-offering in a state of purity for am ha-arets.
} 
not with sex). As the priests were careful to eat their own foods in a state of purity, also others -- although they refrained only from specific sources of contamination, such as menstruation and semen -- made sure to purify specifically before they ate. In Late Antique Palestine, menstruating women were regularly excluded from food preparation, besides their limitations with regard to sexual relations. ${ }^{29}$ Eating in a state of purity was considered a widespread value, although it was maintained on differing levels of expertise. Furthermore, although the rabbis distinguished their own level of observance from that of others, the am ha-arets, they promoted a view of purity suitable to popular sentiments, as their vehement adoption of hand-washing reveals. This complex system of purity observance combines biblical commandments and popular interests, and instead of replacing the priestly purity agenda, it worked to support it in wider social circles. The literary sources testify then to the richness of meanings of purity and the interdependence between them, and the material finds corroborate a multifaceted image of this purity space. Instead of setting the evidence for popular purity as an alternative to the elitist purity of the priests and rabbis, which avoids them and skips directly back to scripture, I suggest describing the purity scene through the ongoing interplay between its different participants.

\section{Purity and Jewish Society}

The image of Jewish society in antiquity underwent a radical reevaluation in the last decades, with the marginalization of the Pharisees and rabbis as leading groups in favor of a more Hellenized or Romanized depiction of general Jewish society. More recently, a milder and traditionally committed version of this form of popular Judaism evolved, famously coined "Common Judaism" by Ed Sanders. In the last chapter, Miller seeks to move beyond this social category, arguing that it does not take into account the considerable overlap between the different groups nor the inability to completely separate them. One receives the impression that Common Judaism was one of many forms of "Judaism", with its own separate set of ideals and practices, while archaeology reveals that we are actually facing a compound of varying cultural expressions within a shared space. Miller terms this space "Complex Common Judaism" (320). As he stresses, archaeological remains do not lend themselves to specific group identities, but they reflect the complexity of Jewish society as a whole. While not eliminating group differences it demands a more sophisticated account of the

\footnotetext{
${ }^{29}$ This aspect of menstrual impurity is most explicit in the text comparing purity practices in Palestine and Babylonia, Ha-hilukim sh-ben Anshei Mizrach u-vnei Eretz Israel (Marguliouth ed. p. 79).
} 
relationship between the different components of this compound. Miller particularly points out the difficulty of setting clear boundaries between rabbis and others during the post $70 \mathrm{CE}$ era. In contrast to the dominant scholarly tendency to separate rabbinic and non-rabbinic Judaism, Miller most arguably claims that "non-rabbinic" Judaism does not stand in and by itself, and the rabbis on their part actually valued popular customs and identified themselves with the larger community.

No doubt, Miller's position is an important corrective to current scholarly trends, that in their eagerness to downplay rabbinic influence did not offer a reasonable account of this non-rabbinic Judaism, and arrived at extreme conclusions concerning its assimilation into the Roman milieu. ${ }^{30}$ Clearly, the material identity signifiers of Jewish settlements during the entire Roman period, of which the ritual baths are the most prominent, testify to the enduring vibrancy of Jewish material culture through political and social changes, and to the dominance of ritual practice in shaping Jewish space and distinct identity. The continuity of common ritual material culture surely undermines any claim of extreme cultural fluctuations during the Roman period; does it also inform us of the internal forces that shaped the complex of Jewish society? At this point, there seems to be some tension between the last chapter underlining the difficulty to distinguish Common and rabbinic Judaism and the emphasis upon the unique features of popular purity in the previous chapters. One element is however persistent: Miller recurrently characterized common Judaism through its turn to Scripture. In his view, its affinity to rabbinic practice does not derive from the rabbis' leading social role or authority (he is very careful not to attribute them) but from the shared commitment to the biblical heritage. This, according to Miller, seems to be the constitutive element of the "Complex Common Judaism".

Miller's subtle approach clearly advances our understanding of Judaism in antiquity far beyond conventional dichotomies; at the same time, I believe this very last point, which underlies the book's overall case for "common purity", deserves reexamination. The claim that common Judaism is characterized by its shared reliance on biblical law, does not take into account the diverse manifestations of the biblical heritage within the range of Jewish and Christian identities, including a variety of approaches to purity among "Jewish-Christian" groups. We know of Christian groups who maintained purification after menstruation and after sexual relations, ${ }^{31}$ but at the same time left no designated installations for that sake. The crucial element, then, is not the biblical

\footnotetext{
${ }^{30}$ Following Schwartz 2001.

${ }^{31}$ As we learn from the Ps. Clementine Homilies and Recognitions and from the Didascalia Apostolorum (Reed 2012).
} 
roots of the ritual baths and of the aspiration for purity but the continuity of the specific material culture from its Second Temple roots and the choice to maintain this specific ritual complex. Furthermore, this material tradition was shaped within a distinctive legal framework, and it therefore owes its persistence to the ongoing interplay between common interests and legal expertise. Beyond the distant and amorphous biblical foundation, the persistence of this material culture depended on the continued collaboration of common purity observance with the only religious elite known from Jewish society in Palestine of the Roman period. 


\section{List of References}

Adler, Y.

$2014 \mathrm{a}$

Tosefta Shabbat 1:14 - 'Come and

See the Extent to which Purity

had Spread': An Archaeological

Perspective on the Historical

Background to a Late Tannaitic

Passage. Pp. 63-82 in Talmuda de-

Eretz Israel: Archaeology and the

Rabbis in Late Antique Palestine, eds. S. Fine and A. Koller. Studia Judaica 73. Berlin: De Gruyter.

$2014 b$

The Myth of the 'Osar in Second Temple Period Ritual Baths: An Anachronistic Interpretation of a Modern-Era Innovation. Journal of Jewish Studies 64: 263-283.

Alon, G.

1977

Jews, Judaism and the Classical

World. Jerusalem: Magnes Press.

Amit, D. and Zissu, B.

2008

Common Judaism, Common Purity and the Second Temple Period Miqwa'ot (Ritual Immersion Baths). Pp. 47-62 in Common Judaism: Explorations in Second Temple Judaism, eds. W. O. McCready and A. Reinhartz. Minneapolis: Fortress Press.
Balberg, M.

2014

Purity, Body and Self in Early

Rabbinic Literature. Berkeley:

University of California Press.

Elitsur, Y.

1999

Ritual Pools for Immersion of Hands. Cathedra 91: 169-172 (in Hebrew)

Furstenberg, Y.

2015

Outsider Impurity: Trajectories of Second Temple Separation Traditions in Tannaitic Literature. Pp. 40-68 in Tradition, Transmission, and Transformation from Second Temple Literature through Judaism and Christianity in Late Antiquity, eds. M. Kister, H. Newman, M. Segal and R. Clements. Leiden: Brill.

2016a

Purity and Community in Antiquity: Traditions of the Law between Second Temple Judaism and the Mishnah. Jerusalem: Magnes Press (in Hebrew).

$2016 b$

Initiation and the Ritual Purification from Sin: Between Qumran and 
the Apostolic Tradition. Dead Sea Discoveries 23: 365-394.

Goodman, M.

2007

Judaism in the Roman World:

Collected Essays. Leiden: Brill.

Grossberg, A.

2007

The Miqva'ot (Ritual Baths) at Masada. Pp. 95-126 in Masada III:

The Yigal Yadin Excavations, 1963 1965, ed. J. Aviram. Jerusalem: Israel Exploration Society.

Kiperwasser, R.

2012

The Immersion of Baallei Qerain. Jewish Studies Quarterly 19: 311338.

Mason, S.

1990

Pharisaic Dominance before 70

$\mathrm{CE}$ and the Gospels' Hypocrisy Charge (Matt.23:2-3). Harvard Theological Review 84: 363-381.

Neusner, J.

1978

Comparing Judaisms. History of Religions 18: 177-191.

Reed, A.Y.

2012

Parting Ways over Blood and

Water? Beyond "Judaism" and
"Christianity" in the Roman Near East. Pp. 227-59 in La croisée des chemins revisitée: Quand l'"Eglise" et la "Synagogue" se sont-elles distinguées? eds. S. C. Mimouni and B. Pouderon. Paris: Editions de Cerf.

Regev, E.

1996

Ritual Baths of Jewish Groups and Sects in Second Temple Period. Cathedra 79: 3-21 (in Hebrew).

2000

Pure Individualism: The Idea of Non-Priestly Purity in Ancient Judaism. Journal for the Study of Judaism in the Persian, Hellenistic and Roman Period 31: 176-202.

Reich, R.

2013

Jewish Ritual Baths in the Second Temple, Mishnaic and Talmudic Period. Jerusalem: Ben Zvi (in Hebrew).

Sanders, E.P.

1990

Jewish Law from Jesus to Mishna: Five Studies. London and Philadelphia: SCM Press.

1994

Judaism: Practice \& Belief 63 BCE-66 CE. London: SCM Press. 
Schwartz, S.

2001

Imperialism and Jewish Society:

200 BCE to 640 CE. Princeton:

Princeton University Press.

Stroumsa, G.

2009

The End of Sacrifice: Religious

Transformations in Late Antiquity.

Chicago: University of Chicago

Press. 